Akreditasi Ristekdikti,

No: 30/E/KPT/2019 (Sinta 4)

Paradigma,

DOI: https://doi.org/10.31294/p.v23i2.11170

Vol. 23, No. 2, September 2021

P-ISSN 1410-5063, E-ISSN: 2579-3500

\title{
Penerapan Metode Rapid Application Development Dalam Pengembangan Sistem Informasi Akademik Berbasis Web
}

\author{
Riska Aryanti ${ }^{1}$, Eka Fitriani ${ }^{2}$, Dian Ardiansyah ${ }^{3}$, Atang Saepudin ${ }^{4}$ \\ ${ }^{1}$ Teknik \& Informatika, Universitas Bina Sarana Informatika \\ riska.rts@bsi.ac.id \\ ${ }^{2}$ Teknik \& Informatika, Universitas Bina Sarana Informatika \\ eka.ean@bsi.ac.id \\ ${ }^{3}$ Teknik \& Informatika, Universitas Bina Sarana Informatika \\ dian.did@bsi.ac.id \\ ${ }^{4}$ Teknik \& Informatika, Universitas Bina Sarana Informatika \\ atang.aug@bsi.ac.id
}

\begin{abstract}
Abstrak - SMA Panca Moral Cikampek merupakan suatu perwujudan dalam membentuk, mendidik genarasi muda bangsa Indonesia. Semakin bertambahnya jumlah siswa setiap tahunnya, dituntut ketepatan dan ketelitian dalam memberikan suatu informasi yang akurat dan tepat kepada siswa tanpa adanya perulangan data atau informasi yang sama. SMA Panca Moral Cikampek sangat membutuhkan adanya sebuah sistem yang dapat menunjang dalam proses penyajian informasi akademik. Untuk menangani masalah tersebut maka dibutuhkan suatu sistem Informasi Akademik Berbasis Web Pada SMA Panca Moral Cikampek sebagai salah satu solusi untuk memberikan sebuah informasi secara akurat, cepat dan tepat. Sistem informasi akademik yang ditawarkan dapat mengelola mengenai informasi akademik baik data absensi siswa, absen mengajar masuk dan absen mengajar guru, mengelola data nilai, jadwal pelajaran, jadwal mengajar guru, serta dapat menerbitkan informasiinformasi yang berhubungan dengan akademik. Pengembangan sistem informasi akademik berbasis web ini menggunakan metode rapid application development $(R A D)$, model pengembangan ini digunakan karena model ini dianggap model dengan mengutamakan waktu, sehingga pengerjaannya relatif singkat sehingga dengan adanya pengembangan sistem informasi ini dapat berguna dalam memberikan kemudahan baik pelajar maupun kepada pengajar.
\end{abstract}

Kata Kunci: Sistem Informasi Akademik, Pengembangan Sistem Informasi, Rapid Aplication Development $(R A D)$.

Abstract - SMA Panca Moral Cikampek is an embodiment in shaping, educating the young generation of the Indonesian nation. The increasing number of students each year, required precision and accuracy in providing a timely and accurate information to students without looping the same data or information. SMA Panca Moral Cikampek very requires a system that can support the process of presenting academic information. To deal with these problems we need a system of Web-Based Academic Information Panca Moral Cikampek In high school as one solution to provide an information accurately, quickly and accurately. The academic information system offered is able to manage academic information both student attendance data, teaching absenteeism and teacher teaching absences, managing grade data, lesson schedules, teacher teaching schedules, and can publish information related to academics. Development of information system web-based academic is using rapid application development (RAD), a development model used for this model is considered a model with emphasis on time, so that the process is relatively short so that with the development of information systems can be useful in providing convenience both students and to the teachers.

Keywords: Academic Information System, Information System Development, Rapid Aplication Development $(R A D)$.

\section{PENDAHULUAN}

Semakin berkembangnya teknologi informasi yang saat ini sudah memasuki disegala bidang, seperti bidang kesehatan, pendidikan, di bidang bisnis jual beli serta pemerintahan. Banyak kemudahan dengan adanya teknologi informasi saat ini terutama dari segi efesiensi, keakuratan dan kebaharuan informasi 
yang dihasilkan dari teknologi informasi. Misalnya dalam bidang kesehatan seperti Sistem Informasi Sistem Informasi Rawat Inap Pasien, Rekam Medik, Sistem Informasi Stok Obat, dan masih banyak lagi sistem informasi yang sudah dimanfaatkan dalam berbagai bidang. Sistem informasi mampu memberikan banyak kemudahan dalam proses pengolahan data, dimana proses pengolahan data yang biasa dilakukan secara manual dapat diterapkan menjadi sistem komputerisasi yang terintegrasi, dengan demikian data dapat disimpan secara terstruktur sehingga lebih mudah untuk dikelola (Tommy \& Prawira, 2015). Oleh karena itu dengan dukungan ilmu pengetahuan dan teknologi maka diperlukan sistem kerja yang cepat dengan dibuatnya sistem informasi yang lebih luas mengenai sekolah tersebut.

Sistem informasi akademik merupakan suatu kegiatan administrasi akademis yang mengatur pengarsipan yang berkaitan dengan data siswa, data guru, serta rencana kegiatan yang dapat dikelola dan untuk memperoleh suatu informasi dengan mudah dan cepat (Tommy \& Prawira, 2015).

Penelitian sebelumnya telah dilakukan oleh Muhammad Ali, adanya penggunaan teknologi sistem informasi akademik terbukti mampu mengurangi kelemahan sistem dan memberikan kontribusi kepada guru dan pihak sekolah serta siswa(AS \& Septiani, 2016), juga telah dilakukan oleh Agus Tomy dimana dengan diterapkannya sistem informasi akademik berbasis web dapat meningkatkan efektifitas dan efisiensi kerja pegawai dalam memberikan pelayanan kepada siswa, efektifitas dan efisiensi kerja guru dalam proses belajar mengajar serta memudahkan kontrol kepala sekolah terhadap kinerja guru dan perkembangan prestasi siswa(Tommy \& Prawira, 2015).

Atas dasar berikut penulis muncul ide untuk melakukan sebuah penelitian dalam aspek dunia pendididkan, yang mana objek yang difokuskan penulis yakni SMA Panca Moral Cikampek, yang mana salah satu sekolah yang belum menerapkan sistem informasi akademik. Meninjau pentingnya sistem informasi akademik berbasis web sangat berguna dalam memberikan kemudahan dalam hal pengolahan data nilai baik kepada pengajar ataupun pelajar di SMA Panca Moral Cikampek. Dengan pembuatan sistem informasi akademik berbasis web maka siswa mendapatkan informasi-informasi yang berhubungan dengan akademik secara lengkap dan praktis tanpa datang ke sekolah melainkan cukup mengaksesnya dengan menggunakan internet. Peneliti dalam membangun sistem tersebut menggunakan metode pengembangan Rapid Application Development (RAD), metode ini digunakan karena metode RAD dapat mempersingkat waktu dalam pembangunan sistem informasi dari pada metode tradisional lainya(Aini \& Wicaksono, 2019), juga dengan menggunakan metode RAD sistem yang dikembangkan lebih cepat tersampaikan ke user dan tidak diperlukan dalam menunggu fitur yang lain terselesaikan(Widiyanto, 2018).

RAD merupakan metode pengembangan sekuensisal linier yang memusatkan pada siklus waktu pengembangan dengan singkat dalam pengembangan perangkat lunak (Kendall, 2011), metode pengembangan sistem dengan RAD sudah banyak digunakan dalam berbagai bidang, diantaranya dalam bidang pendidikan telah dilakukan oleh Nur Aini membahas mengenai pembangunan sistem informasi perpustakaan (Aini \& Wicaksono, 2019), juga telah dilakukan oleh Jijon Raphita Sagala dimana pada penelitian ini membahas mengenai pengembangan sistem informasi penjadwalan belajar mengajar(Sagala, 2018), sedangkan dalam bidang bisnis membahas mengenai perancangan sistem e-commerce (Saepudin et al., 2021), bidang pariwisata Pariwisata oleh Meidyan Permata Putri membahas mengenai rancang bangun website service guide "Waterfall Tour South Sumatera" (Puteri \& Effendi, 2018) dan Sofiansyah Fadli membahas mengenai pengembangan sistem reservasi dan penyewaan kamar hotel(Fadli, 2018).

\section{METODOLOGI PENELITIAN}

Metodologi pada penelitian ini meliputi:

\section{Teknik Pengumpulan Data}

Teknik pengumpulan data yang digunakan dalam penelitian ini, adalah:

a. Observasi

Observasi merupakan pengamatan secara langsung terhadap suatu kegiatan yang sedang berjalan. Pada tahapan ini penulis mengamati secara langsung terhadap objek yang penulis teliti, yakni SMA Panca Moral Cikampek, karena sistem informasi akademik masih manual.

b. Wawancara

Pada tahapan ini penulis melakukan tanya jawab langsung kepada Guru, Siswa dan staf Tata Usaha mengenai semua hal yang berkaitan dengan sistem informasi akademik.

c. Studi Pustaka

Pada metode ini yang dilakukan adalah mencari referensi yang mendukung dalam pendefinisian masalah yang berkaitan dengan tema penelitian melalui buku-buku, jurnal maupun internet.

\section{Teknik Pengambangan Sistem}

Adapun teknik pengembangan sistem dalam penelitian ini yaitu menggunakan model Rapid Application Development (RAD), metode ini dianggap metode perangkat lunak yang mengutamakan waktu, sehingga pengerjaannya dapat dilakukan dengan waktu yang relatif lebih cepat. (Puteri \& Effendi, 2018). 


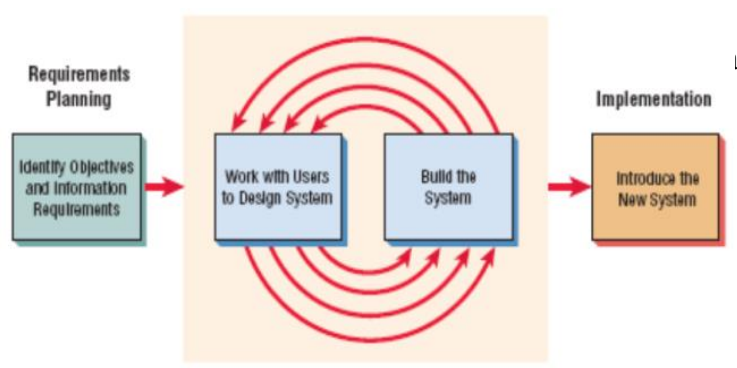

Sumber: (Kendall, 2011)

Gambar 1. Tahapan Metode RAD

Metode RAD terdiri dari 3 tahapan yang terstruktur dan saling bergantung disetiap tahapannya:

a. Requirement Planning (Rencana Kebutuhan) Pada tahapan ini pengguna dan analisis melakukan semacam pertemuan untuk mengidentifikasi tujuan dari aplikasi atau batasan dan obyektifitas dari sistem untuk pemecahan masalah bisnis.

b. Design Workshop.

Design Workshop RAD merupakan tahapan dimana perancangan sistem melibatkan Pengguna (Aini \& Wicaksono, 2019), tujuan dari tahapan ini untuk merancang seluruh kegiatan dari arsitektur sistem secara menyeluruh dan meningkatkan pemahaman atas permasalahan berdasarkan analisa yang dilakukan(Kosasi, 2015)

c. Implementation

Implementation merupakan tugas programmer untuk meneruskan dalam bentuk coding melalui tinjauan pemrograman berdasarkan rancangan sistem yang telah dibuat oleh desainer sistem (Aswati et al., 2017).

\section{HASIL DAN PEMBAHASAN}

\section{Rencana Kebutuhan (Requirement Planning)}

Rencana kebutuhan sistem adalah, pada tahapan ini penulis gambarkan dengan menggunakan activity diagram, untuk lebih jelasnya dapat dilihat pada gambar 2 .

Berikut merupakan gambaran activity diagram dari sistem informasi akademik di SMA Panca Moral Cikampek:

a. Membuat Jadwal

Bagian Kurikulum membuatkan jadwal pelajaran dan jadwal mengajar guru, lalu jadwal tersebut diberikan kepada kepala sekolah, jika jadwal telah disetujui oleh kepala sekolah maka jadwal mengajar guru diberikan kepada guru pengampu dan jadwal pelajaran diberikan kepada wali kelas, untuk dipublikasikan kepada siswa.

b. Absensi

Kemudian guru melakukan absen mengajar dari jadwal yang telah dibuat oleh bagian kurikulum, setelah melakukan absensi, guru dapat mengajar dan melakukan absen siswa dan siswa dapat mengikuti pelajaran. Kemudian setiap akhir semester guru membuat rekap absensi siswa untuk diberikan kepada wali kelas .

c. Input Nilai

Guru dapat menginput nilai tugas ataupun nilai ujian sesuai dengan kelas yang diampu, dimana nilai tersebut akan diberikan kepada walikelas untuk diisi pada lembar sementara sebagai bayangan dari nilai raport yang nantinya akan diserahkan kepada siswa.

d. Informasi umum

selain membuat jadwal Bagian Kurikulum juga memberikan informasi terbaru mengenai civitas akademika, kemudian informasi tersebut diletakan didinding sekolah, sehingga siswa dan guru dapat melihat informasi tersebut.

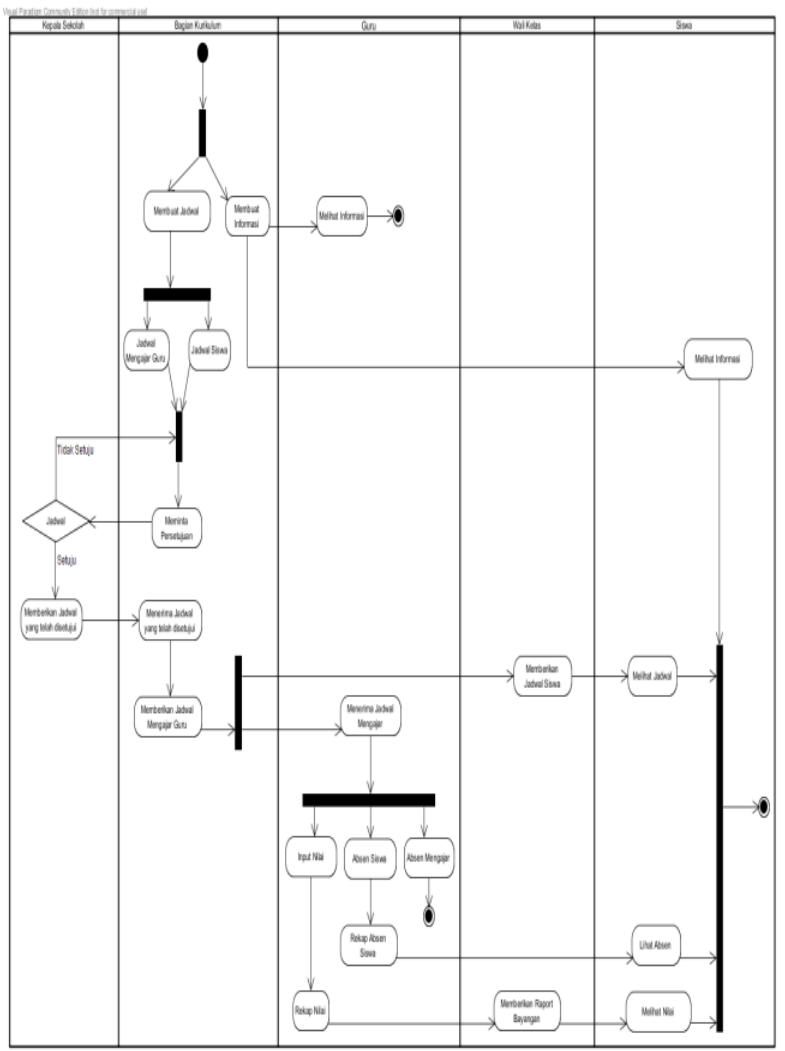

Sumber: (Aryanti et al., 2021)

Gambar 2. Activity Diagram Sistem Informasi Akademik SMA Panca Moral Cikampek

\section{Design Workshop}

Design Workshop yang dilakukan peneliti dalam penelitian ini adalah tahap desain dan penyempurnaan. Yang mana pada penelitian ini penulis gambarkan dengan menggunakan Use Case Diagram dan desain database digambarkan dengan ERD (Entity Relationship Diagram) dan LRS (Logical Record Structure).

\section{a. Use Case Diagram}

Berdasarkan hasil wawancara dilakukan peneliti dengan petugas Tata Usaha SMA Panca Moral Cikampek, berikut ini daftar kebutuhan pengguna 
Sistem Informasi Akademik SMA Panca Moral Cikampek dapat dilihat pada Tabel 1.

\begin{tabular}{|c|c|c|}
\hline NO & $\begin{array}{c}\text { NAMA } \\
\text { PEGGUNA }\end{array}$ & DESKRIPSI \\
\hline 1. & Administrator & $\begin{array}{ll} & \text { Mengelola Data Ampu } \\
\text { - } & \text { Mengelola Data Tingkat } \\
\text { - } & \text { Mengelola Data Mata } \\
& \text { Pelajaran } \\
\text { - } & \text { Mengelola Data Jadwal } \\
\text { - } & \text { Mengelola Data Kelas } \\
\text { - } & \text { Mengelola Data Guru } \\
\text { - } & \text { Mengelola Data Absensi } \\
& \text { Guru } \\
\text { - } & \text { Mengelola Data Siswa } \\
\text { - } & \text { Mengelola Data Nilai } \\
& \text { Siswa } \\
\text { - } & \text { Mengelola Informasi } \\
& \text { Terbaru } \\
\text { - } & \text { Mengelola Kalender } \\
& \text { Akademik } \\
\text { - } & \text { Mengelola Data Pengguna } \\
\text { - } & \text { Setting Semester Aktif }\end{array}$ \\
\hline 2. & Guru & $\begin{array}{ll}\text { - } & \text { Melakukan Absensi Masuk } \\
\text { dan Absensi Keluar } \\
\text { Mengajar } \\
\text { - } & \text { Melihat Data Pribadi Guru } \\
\text { - } & \text { Melihat Jadwal Mengajar } \\
\text { - } & \text { Melakukan Absensi } \\
\text { Mengajar } \\
\text { - } & \text { Melakukan Absensi Siswa } \\
\text { - } & \text { Melihat Rekap Absensi } \\
& \text { Siwa } \\
\text { - } & \text { Menginput Nilai } \\
\text { - } & \text { Melihat Data Kalender } \\
& \text { Akademik } \\
\text { - } & \text { Melihat Informasi Terbaru }\end{array}$ \\
\hline 3. & Siswa & 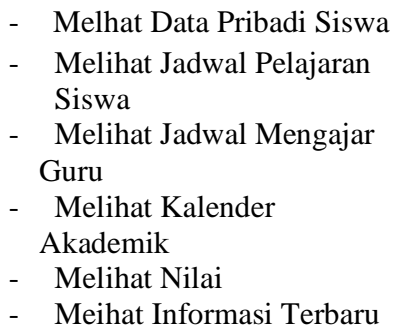 \\
\hline
\end{tabular}

Sumber: Hasil Penelitian (2021)
1) Use Case Diagram Halaman Administrator

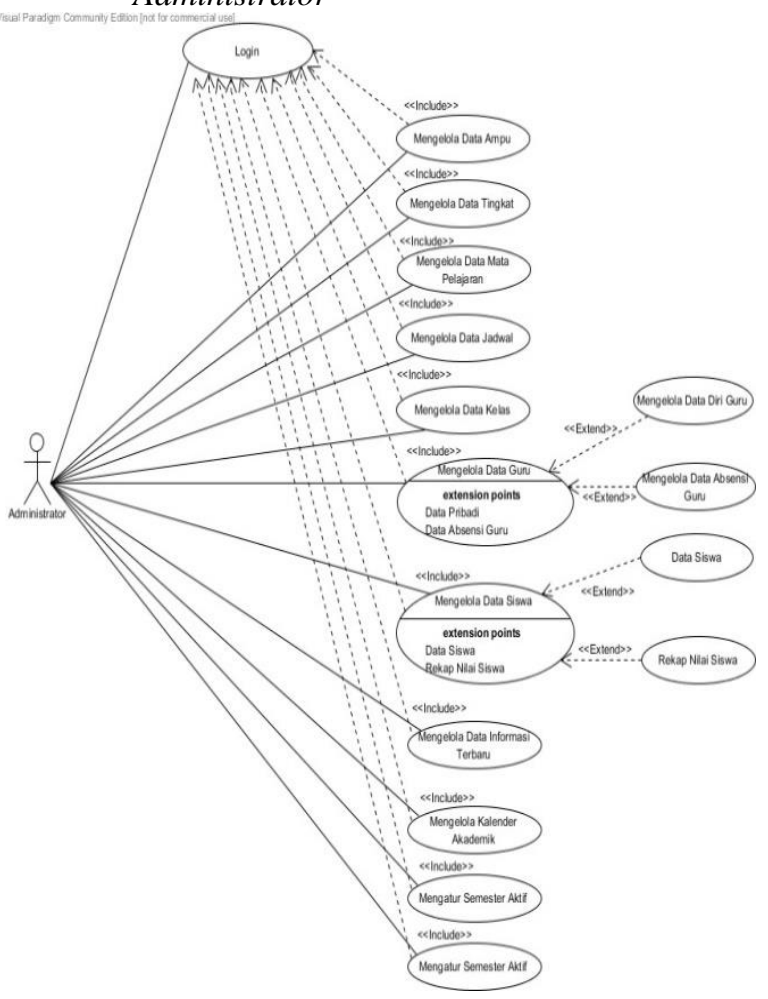

Sumber: (Aryanti et al., 2021)

Gambar 3. Use Case Diagram Halaman Administrator

2) Use Case Diagram Halaman Guru

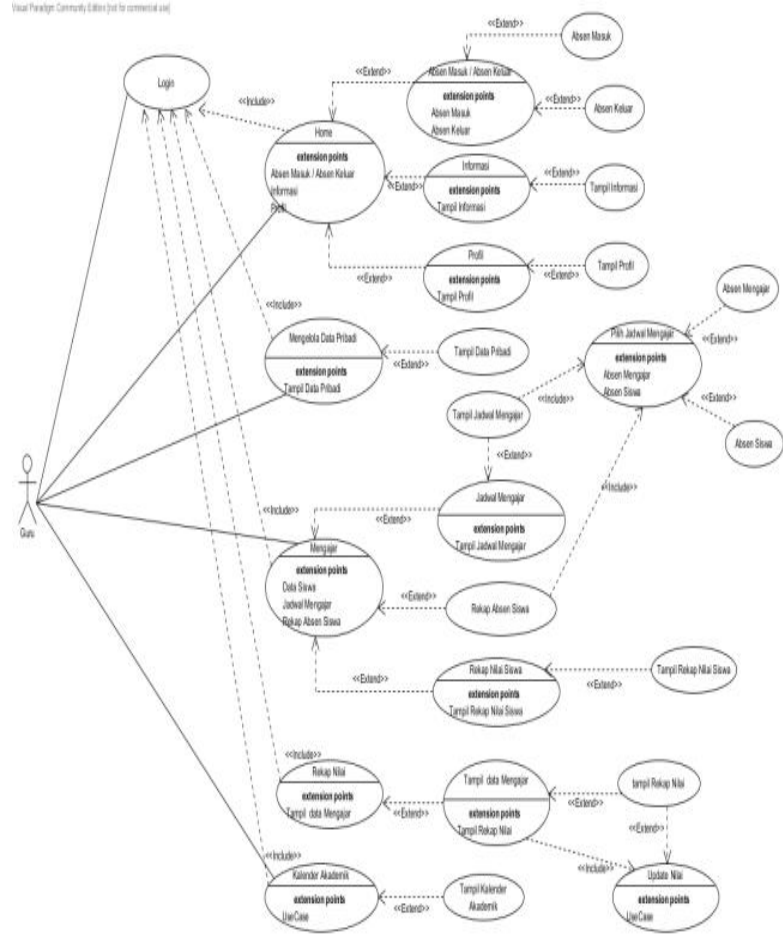

Sumber: (Aryanti et al., 2021)

Gambar 4. Use Case Diagram Halaman Guru 
3) Use Case Diagram Halaman Siswa

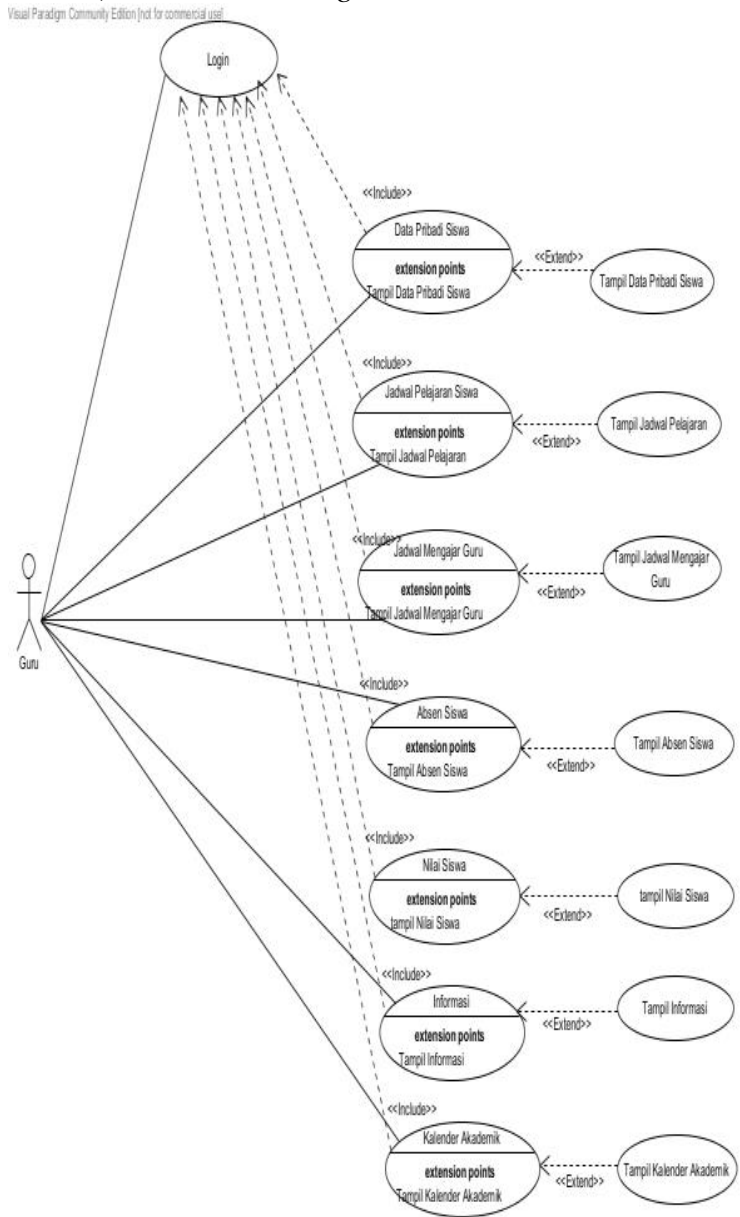

Sumber: (Aryanti et al., 2021)

Gambar 5. Use Case Diagram Halaman Siwa

\section{b. Desain Database}

\section{1) ERD (Entity Relationship Diagram)}

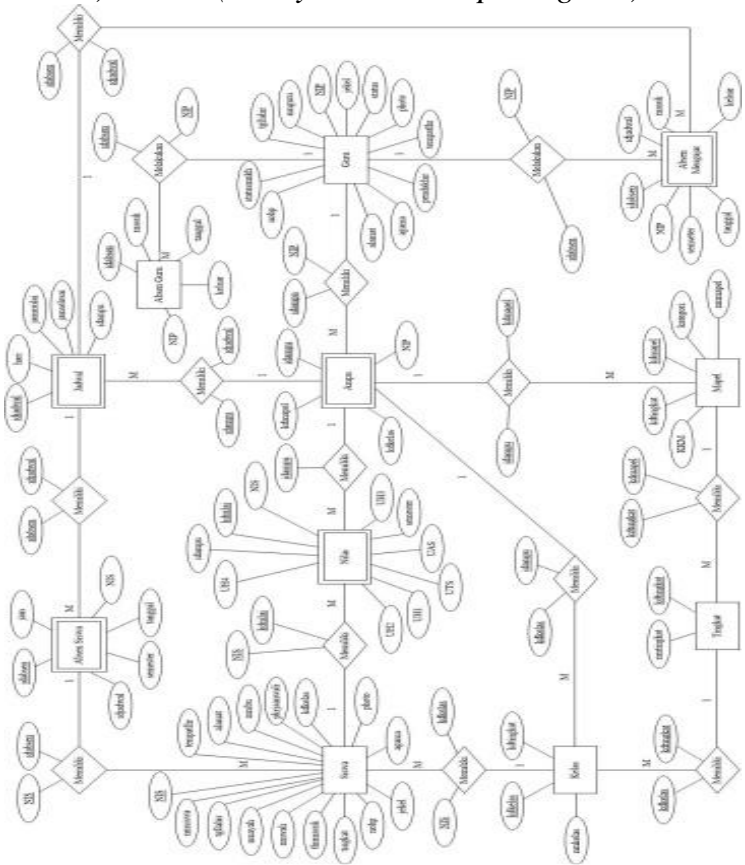

Sumber: (Aryanti et al., 2021)

Gambar 6. ERD (Entity Relationship Diagram)

\section{2) LRS (Logical Record Structure)}

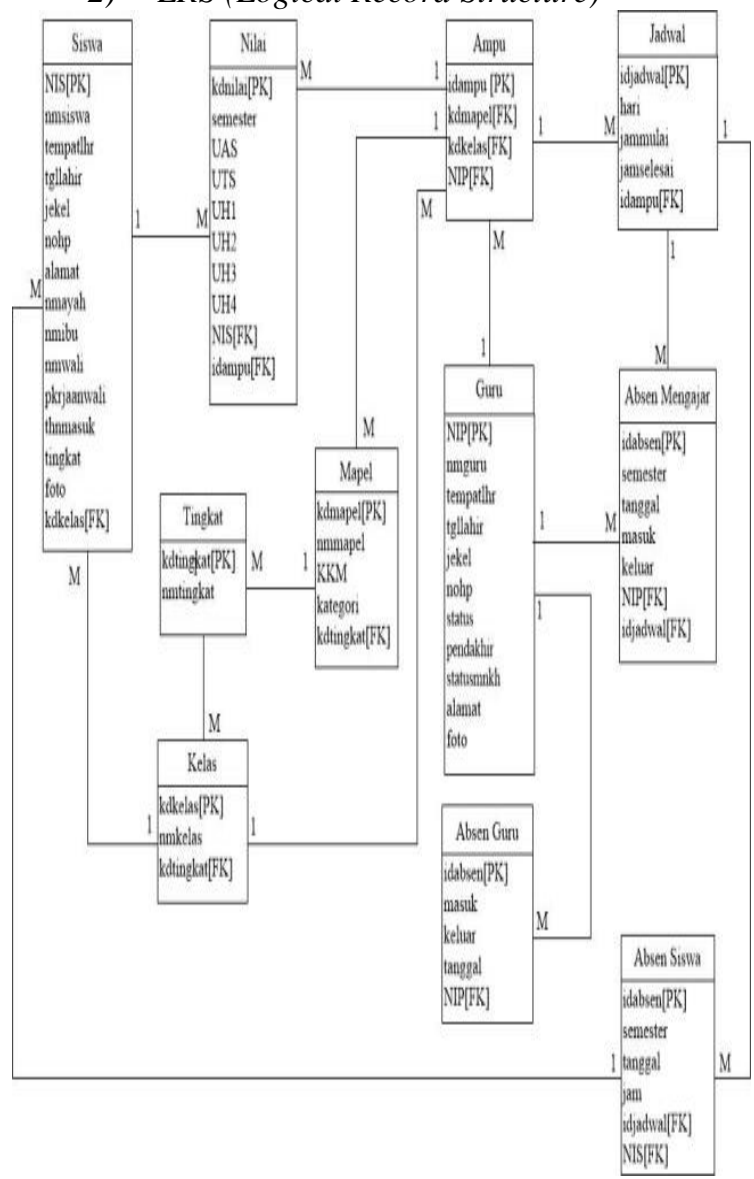

Sumber: (Aryanti et al., 2021)

Gambar 7. LRS (Logical Record Structure)

\section{Implementasi (Implementation)}

Berikut merupakan tampilan antarmuka website sistem informasi akademik SMA Panca Moral Cikampek:

a. Tampilan Antarmuka Home

Berikut adalah tampilan antarmuka home dapat dilihat pada gambar 8 .

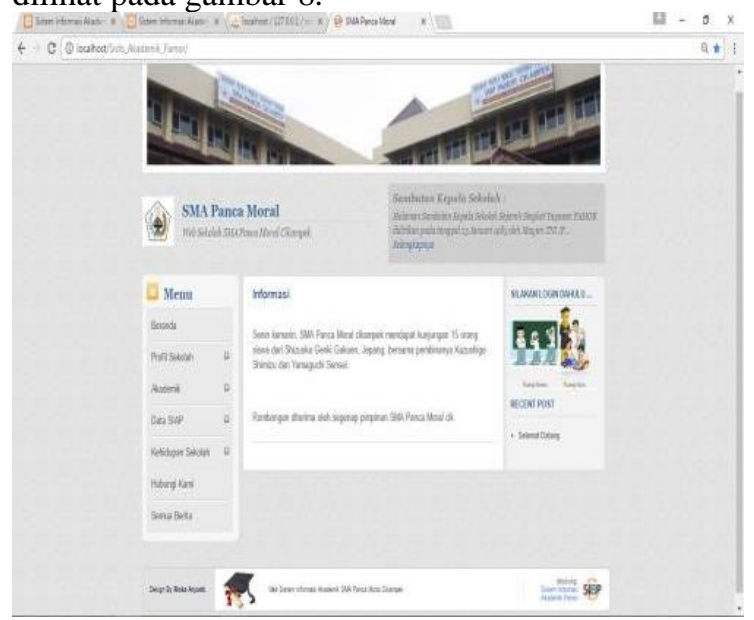

Sumber: (Aryanti et al., 2021)

Gambar 8. Tampilan Antarmuka Home 
b. Tampilan Antarmuka Login Administrator, Guru dan Siswa

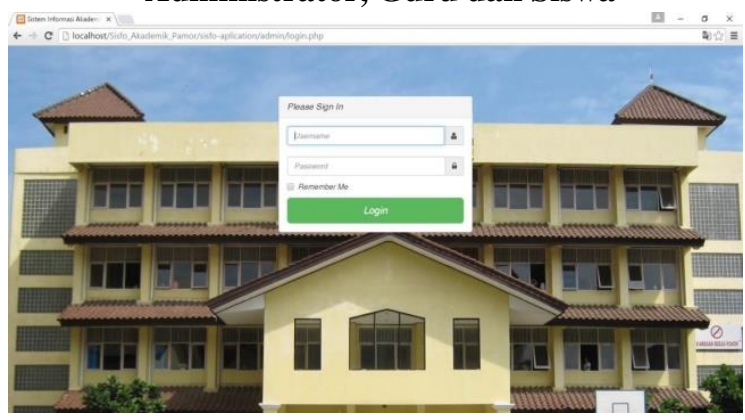

Sumber: (Aryanti et al., 2021)

Gambar 9. Tampilan Antarmuka Login Administrator

c. Tampilan Antarmuka Halaman Administrator

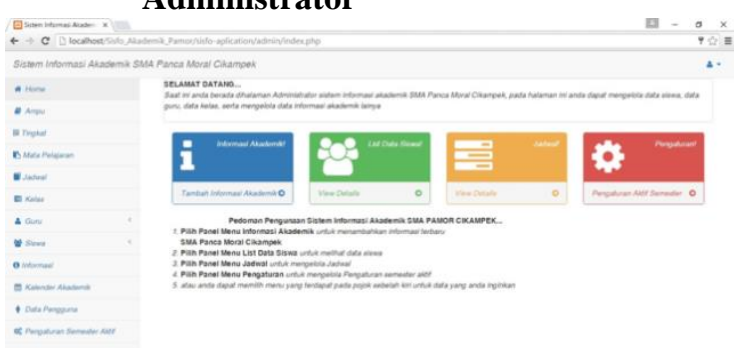

Sumber: (Aryanti et al., 2021)

Gambar 10. Tampilan Antarmuka Halaman Administrator

\section{d. Tampilan Antarmuka Halaman Siswa}

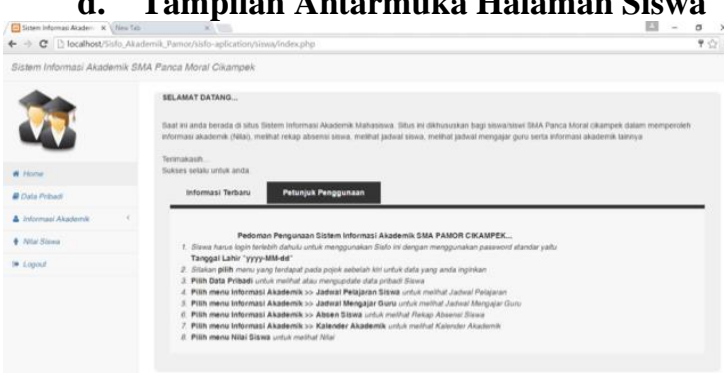

Sumber: (Aryanti et al., 2021)

Gambar 11. Tampilan Antarmuka Halaman Siswa

\section{e. Tampilan Antarmuka Nilai Siswa}

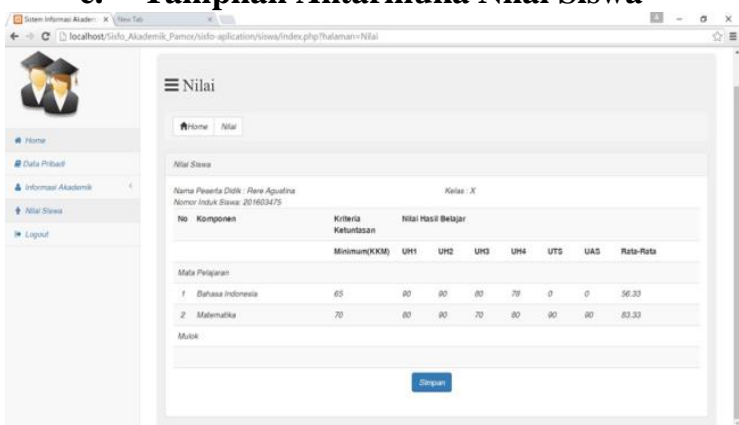

Sumber: (Aryanti et al., 2021)

Gambar 12. Tampilan Antarmuka Nilai Siswa

\section{f. Tampilan Antarmuka Jadwal Pelajaran}

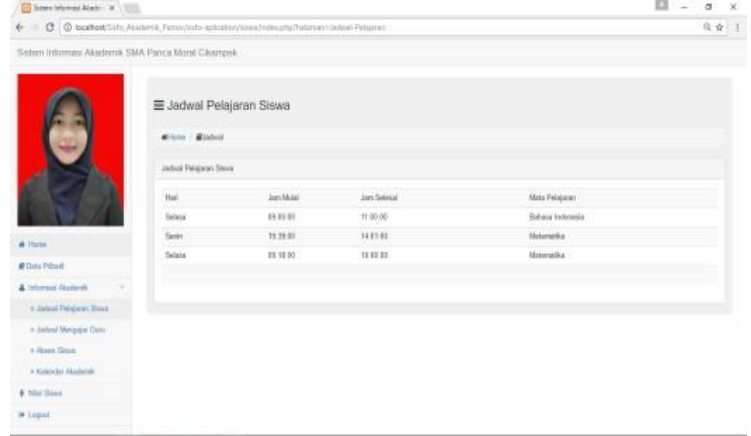

Sumber: (Aryanti et al., 2021)

Gambar 13. Tampilan Antarmuka Jadwal Mengajar

\section{g. Tampilan Antarmuka Halaman Guru}

Sumber: (Aryanti et al., 2021)

Gambar 14. Tampilan Antarmuka Halaman Guru

\section{h. Tampilan Antarmuka Absen Guru}

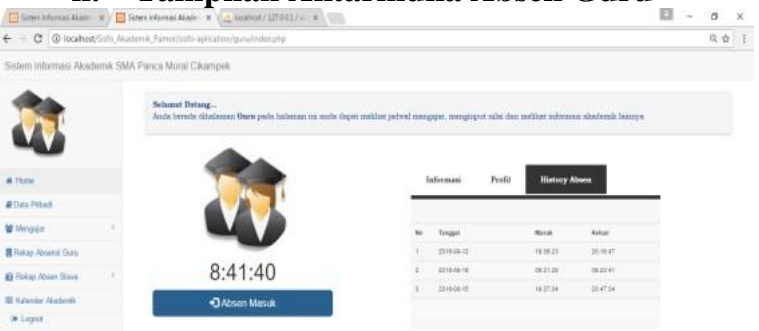

Sumber: (Aryanti et al., 2021)

Gambar 15. Tampilan Antarmuka Absen Guru

\section{i. Tampilan Antarmuka Rekap Absen Guru}

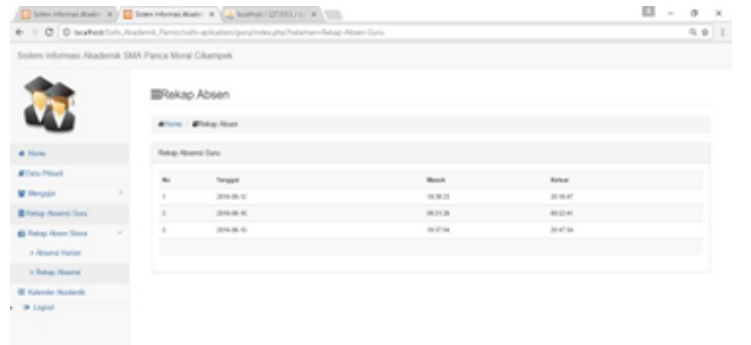

Sumber: (Aryanti et al., 2021)

Gambar 16. Tampilan Antarmuka Rekap Absen Guru 


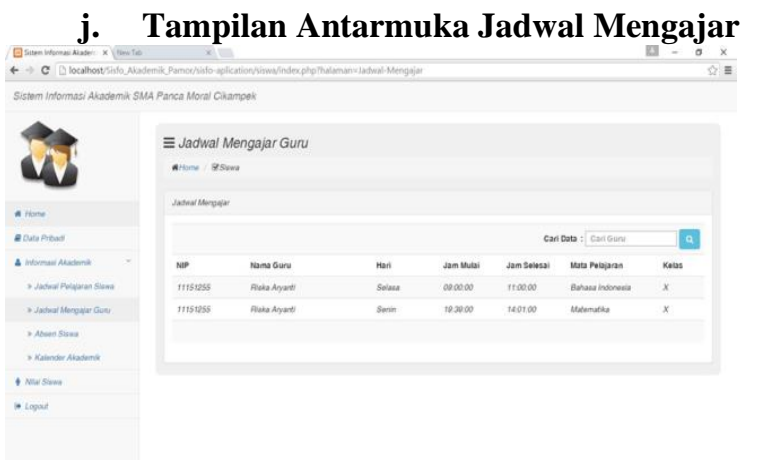

Sumber: (Aryanti et al., 2021)

Gambar 17. Tampilan Antarmuka Jadwal Mengajar

\section{k. Tampilan Antarmuka Input Nilai Siswa}

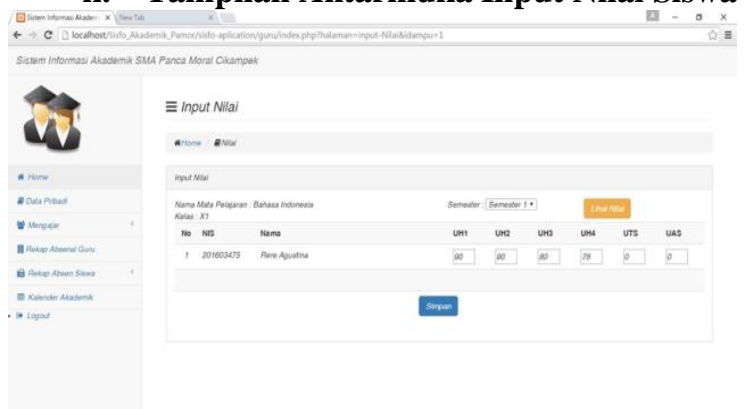

Sumber: (Aryanti et al., 2021)

Gambar 18. Tampilan Antarmuka Nilai Siswa

\section{Tampilan Antarmuka Absensi Siswa}

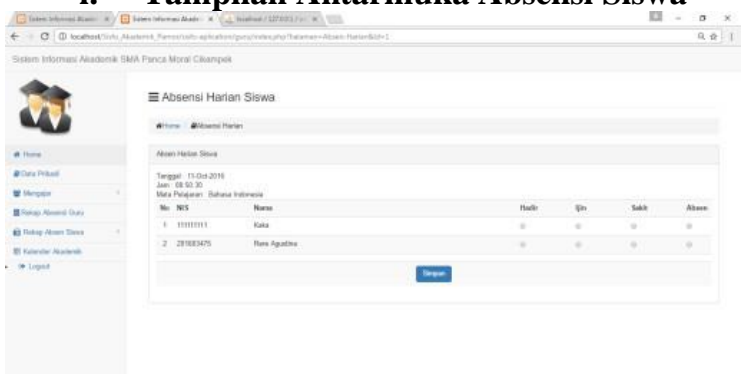

Sumber: (Aryanti et al., 2021)

Gambar 19. Tampilan Antarmuka Absensi Siswa

\section{m. Tampilan Antarmuka Rekap Absensi} Siswa

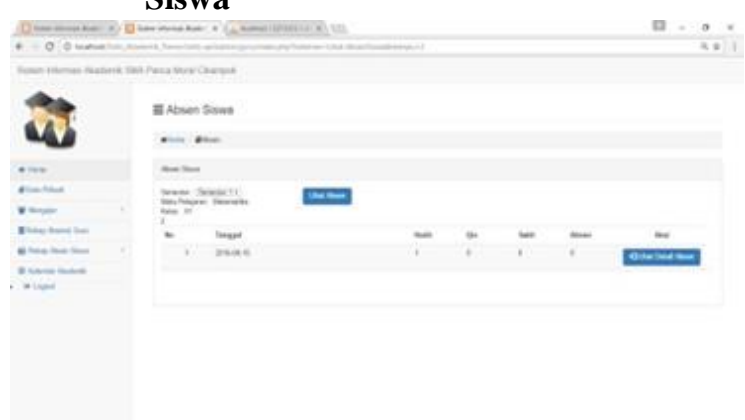

Sumber: (Aryanti et al., 2021)

Gambar 20. Tampilan Antarmuka Rekap Absensi Siswa

\section{KESIMPULAN}

Berdasarkan hasil penelitian bahwa perancangan sistem informasi akademik pada SMA Panca Moral Cikampek telah sesuai dengan hasil analisa dan pemodelan yang dilakukan, sehingga adanya website sistem informasi akademik menggunakan metode Rapid Application Development (RAD) memberikan beberapa keuntungan diantaranya memberikan kemudahan kepada guru untuk melakukan absen masuk dan keluar serta absen mengajar masuk dan absen mengajar keluar. Sedangkan dari sisi siswa dapat dengan mudah mendapatkan informasi mengenai kesiswaan, yaitu seperti jadwal pelajaran, jadwal mengajar guru, melihat nilai dan informasiinformasi terbaru yang diterbitkan oleh pihak sekolah. Pihak sekolah juga dapat mendistribusikan informasi mengenai pembukaan pendaftaran calon mahasiswa dengan segera dan melakukan promosi dengan biaya rendah dan cepat. Dan dapat meningkatnya keefektifitasan dan efisiensi dalam mendistribusikan informasi akademik baik kepada guru, staff pengajar maupun siswa.

\section{REFERENSI}

Aini, N., \& Wicaksono, S. (2019). Pembangunan Sistem Informasi Perpustakaan Berbasis Web menggunakan Metode Rapid Application Development (RAD) (Studi pada : SMK Negeri 11 Malang). J-Ptiik.Ub.Ac.Id, 3(9), 9. http://j-ptiik.ub.ac.id/index.php/jptiik/article/download/6236/2996

Aryanti, R., Fitriani, E., Ardiansyah, D., \& Saepudin, A. (2021). Penerapan Metode Rapid Application Development Dalam Pengembangan Sistem Informasi Akademik Berbasis Web.

AS, M. A., \& Septiani, N. A. (2016). Perancangan Sistem Informasi Akademik Menggunakan Metode Waterfall Studi Kasus: Madrasahaliyah Al- Mansyuriyah Kanza Mekarjaya Tangerang. Jurnal Techno Nusa Mandiri, XIII(2), 1978-2136. http://ejournal.nusamandiri.ac.id/index.php/tec hno/article/view/209

Aswati, S., Ramadhan, M. S., Firmansyah, A. U., \& Anwar, K. (2017). Studi Analisis Model Rapid Application Development Dalam Pengembangan Sistem Informasi. Matrik: Jurnal Manajemen, Teknik Informatika, Dan Rekayasa Komputer, 16(2), 20-27. https://doi.org/https://doi.org/10.30812/matrik. v16i2.10

Fadli, S. (2018). Model Rapid Application Development Dalam Pengembangan Sistem Reservasi Dan Penyewaan Kamar Hotel. JIRE (Jurnal Informatika \& Rekayasa Elektronika), l(1),

57-64. 
https://doi.org/https://doi.org/10.36595/jire.v1i 1.33

Kendall, E. K. and J. E. K. (2011). System Analysis and Design Eighth Edition. New Jersey. Pearson.

Kosasi, S. (2015). Penerapan Rapid Application Development Dalam Sistem Perniagaan Elektronik Furniture. Creative Information Technology Journal (Citec Journal), 2(4), 265-276.

https://doi.org/https://doi.org/10.24076/citec.2 $015 \mathrm{v} 2 \mathrm{i} 4.54$

Puteri, M. P., \& Effendi, H. (2018). Implementasi Metode RAD Pada Website Service Guide "Tour Waterfall South Sumatera." Jurnal Sisfokom (Sistem Informasi Dan Komputer), 7(2), 130-136. https://doi.org/10.32736/sisfokom.v7i2.570

Saepudin, A., Aryanti, R., Fitriani, E., \& Ardiansyah, D. (2021). Perancangan Sistem ECommerce Menggunakan Model Rapid Application Development Pada Pengurus Cabang Judo Karawang. Paradigma - Jurnal Komputer Dan Informatika, 23(1), 25-32.

Sagala, J. R. (2018). Model Rapid Application Development (RAD) Dalam Pengembangan Sistem Informasi Penjadwalan Belajar Mengajar. Jurnal Mantik Penusa, 2(1), 87-90. http://e-

jurnal.pelitanusantara.ac.id/index.php/mantik/a rticle/view/454

Tommy, A., \& Prawira, A. (2015). Perancangan Sistem Informasi Akademik Sekolah Berbasis Web (Studi Kasus SMPK Harapan Denpasar). Jurnal Teknologi Informasi Dan Komputer, $1(1)$, 64-73. http://jurnal.undhirabali.ac.id/index.php/jutik/a rticle/view/24

Widiyanto, W. W. W. (2018). Analisa Metodologi Pengembangan Sistem Dengan Perbandingan Model Perangkat Lunak Sistem Informasi Kepegawaian Menggunakan Waterfall Development Model, Model Prototype, Dan Model Rapid Application Development (RAD). Jurnal INFORMA Politeknik Indonusa Surakarta, 4(1), 34-40. https://doi.org/https://doi.org/10.46808/inform a.v4i1.34

\section{PROFIL PENULIS}

Riska Aryanti, M.Kom. Tahun 2016 lulus dari Program Strata Satu (S1) Program Studi Sistem Informasi di Sekolah Tinggi Manajemen Informatika dan Komputer Nusa Mandiri. Pada Tahun 2018 lulus dari Program Magister (S2) Program Studi Ilmu Komputer di Sekolah Tinggi Manajemen Informatika dan Komputer Nusa Mandiri. Saat ini bekerja sebagai Staff Pengajar (Dosen) di Universitas Bina Sarana Informatika dan menjadi staff LPPM Universitas Bina Sarana Informatika.

Eka Fitriani, M.Kom. Tahun 2016 lulus dari Program Strata Satu (S1) Program Studi Sistem Informasi di Sekolah Tinggi Manajemen Informatika dan Komputer Nusa Mandiri. Pada Tahun 2018 lulus dari Program Magister (S2) Program Studi Ilmu Komputer di Sekolah Tinggi Manajemen Informatika dan Komputer Nusa Mandiri. Saat ini bekerja sebagai Staff Pengajar (Dosen) di Universitas Bina Sarana Informatika dan menjadi staff LPPM Universitas Bina Sarana Informatika.

Dian Ardiansyah, M.Kom. Tahun 2016 lulus dari Program Strata Satu (S1) Program Studi Sistem Informasi di Sekolah Tinggi Manajemen Informatika dan Komputer Nusa Mandiri. Pada Tahun 2018 lulus dari Program Magister (S2) Program Studi Ilmu Komputer di Sekolah Tinggi Manajemen Informatika dan Komputer Nusa Mandiri. Saat ini bekerja sebagai Staff Pengajar (Dosen) di UniversitasBina Sarana Informatika dan menjadi staff Markom Universitas Bina Sarana Informatika.

Atang Saepudin, M.Kom. Tahun 2016 lulus dari Program Strata Satu (S1) Program Studi Sistem Informasi di Sekolah Tinggi Manajemen Informatika dan Komputer Nusa Mandiri. Pada Tahun 2018 lulus dari Program Magister (S2) Program Studi Ilmu Komputer di Sekolah Tinggi Manajemen Informatika dan Komputer Nusa Mandiri. Saat ini bekerja sebagai Staff Pengajar (Dosen) di Universitas Bina Sarana Informatika dan menjadi staff PDPT Universitas Bina Sarana Informatika. 